\title{
PSYCHOSOCIAL INTERVENTION IN SEXUAL VIOLENCE AGAINST CHILDREN: REFLEXIVITY AND PSYCHODRAMATIC RESOURCE
}

\author{
Denise Lima Moreira' ${ }^{1}$, Liana Fortunato Costa2,* (D)
}

\begin{abstract}
This study aims to discuss the reflexivity of female children victims of sexual violence during a psychosocial intervention with a psychodramatic orientation, seeking out to understand the meanings present in the dialogues and plays. The research participants were 13 girls victims of sexual violence perpetrated by an adolescent close relative. Two group sessions records were used to focus on the interpretation of reflexivity on the theme of protection. The results describe the sessions in the organization: warm-up, dramatization and sharing. The discussion focuses on the earnings that play and dramatic plays bring to reflexivity about a topic such as arduous as sexual violence. The creation of a playful environment favors a dialogue between victims and adolescent offenders.
\end{abstract}

KEYWORDS: Sexual offense; Victims; Elaboration; Psychotherapy.

\section{INTERVENÇÃO PSICOSSOCIAL NA VIOLÊNCIA SEXUAL CONTRA CRIANÇAS: REFLEXIVIDADE E RECURSO PSICODRAMÁTICO}

\section{RESUMO}

O objetivo do estudo é discutir a reflexividade de crianças do sexo feminino vítimas de violência sexual durante uma intervenção psicossocial de orientação psicodramática, buscando apreender a perspectiva dos significados presentes nos diálogos e brincadeiras. As participantes da pesquisa foram 13 meninas vítimas de violência sexual perpetrada por adolescente parente próximo. Utilizou-se o registro de duas sessões grupais com foco na interpretação da reflexividade sobre o tema da proteção. Os resultados descrevem as sessões segundo organização de aquecimento, dramatização e compartilhamento. A discussão foca os ganhos que a brincadeira e o jogo dramático trazem para a reflexividade, sobre tema tão árduo como o da violência sexual. A criação de ambiente lúdico favorece o diálogo entre vítimas e adolescentes ofensores.

PALAVRAS-CHAVE: Abuso sexual; Vítimas; Elaboração; Psicoterapia.

\section{INTERVENCIÓN PSICOSOCIAL EN LA VIOLENCIA SEXUAL CONTRA LA NIÑEZ: REFLEXIVIDAD Y RECURSO PSICODRAMÁTICO}

\section{RESUMEN}

El objetivo del estudo es discutir la reflexividad de las niñas víctimas de violencia sexual durante una intervención psicosocial con orientación psicodramática, buscando aprehender la perspectiva de los significados presentes en los diálogos y juegos. Los participantes de la investigación fueron 13 niñas

1.Secretaria de Saúde do Governo do Distrito Federal - Brasília (DF), Brazil.

2.Universidade de Brasília - Brasília (DF), Brazil.

*Corresponding author: lianaf@terra.com.br

Section Editor: Liliana S. Ribeiro

Received: Aug. 24, 2020 - Accepted: Jan. 07, 2021 
víctimas de violencia sexual perpetrada por un familiar cercano adolescente. Se utilizaron dos sesiones grupales para centrarse en la interpretación de la reflexividad sobre el tema de la protección. Los resultados describen las dos sesiones en su organización de calentamiento, dramatización y compartilhamento. La discusión se centra en las ganancias que el juego y el juego dramático aportan a la reflexividad, sobre un tema tan arduo como la violencia sexual. La creación de un ambiente lúdico favorece el diálogo entre víctimas y adolescentes infractores.

PALABRAS CLAVE: Abuso sexual; Víctimas; Elaboración; Psicoterapia.

\section{INTRODUCTION}

There is a consensus that therapeutic interventions with victims of sexual violence are fundamental for their good development after the occurrence of the fact. Exposure to this traumatic situation requires action to restore protection and reduce the harmful effects of the event on its victims (Devlin et al., 2019; Walters, 2017). Many symptoms arise after experiencing violence, which both affect the victim - depression, post-traumatic stress and anxiety - and bring harm to various areas of the life of everyone in the family (Capella et al., 2018; Dorsey et al., 2017; Marra \& Costa, 2018). The text aims to discuss the female children's reflexivity who are victims of sexual violence during a psychosocial intervention with a playful orientation. In this way, it is intended to apprehend the perspective of the meanings present in the dialogues and games on the theme of protection that is to restore from the therapeutic action (Capella et al., 2018; Marra \& Costa, 2016; Webster, 2018).

Therapeutic intervention for victims has been advocated (Aarons, 2004; Dorsey et al., 2017; Navaei et al., 2016; Trivedi \& Rejani, 2016; Webster, 2018) as an important resource for the resumption of individual and family reorganization in cases of intra and extra-family sexual violence. The service models can be family, individual, group, playful, focusing on behavioral changes or focused on attention to the dyads (mother/child, brother/brother). Studies carried out to evaluate the effectiveness of this information have found positive results and demand that these interventions come to be valued as a competent response to the suffering arising from sexual victimization (Dorsey et al., 2017; Mercer, 2017; Navaei et al., 2016; Trivedi \& Rejani, 2016).

Especially in assisting child victims, the play therapy that uses communication and the interpretation of playing has several materials that express reflexivity as a resource to expand the understanding of the adverse situation and the metaphor of verbalization. Psychodrama, a therapeutic approach that works from the construction of a playful environment, is useful in relaxing the field of action with this theme (Marra, 2015). The therapeutic approach to sexual violence requires a connection between various contexts - social assistance, justice, and psychology - to achieve the goals of social and family reorganization and the psychological changes of the victims. Psychodrama has been used in therapeutic actions with other actors in the circuit of perpetration of violence, such as adults and adolescent sexual offenders (Costa, Penso, et al., 2020; Costa, Setubal, et al., 2020; Hollander \& Craig, 2013). In the context, this approach appears as a preferred option, as it contains, in its epistemological and methodological basis, action in a playful context and the creation of original and creative responses (Moreno, 1983, 1993). Therapeutic groups and/or counseling groups have also been shown to be effective, being seen as tools to increase parents' self-efficacy in child sexual abuse cases. Awareness of child sexual abuse and prevention must be increased in society through training programs (Navaei et al., 2016).

The changes resulting from the therapeutic intervention are linked to the presence of people who maintain relationships of support and significant affection with the victims and manage to promote the necessary transformations. The therapeutic effects of the intervention constitute a process that has its follow-up gradually, providing that feelings and states of sadness and anguish walk towards the expression of trust, social approach and emotional well-being (Capella et al., 2018; Mercer, 2017; Walters, 2017). For this reason, it is important to properly understand the child's perception of the protection due and the protection offered by the caregivers and/or those responsible for their safety. 
Except for private clinic situations, the vast majority of victims of sexual violence are treated in public psychology or social service institutions, with referrals being made for psychosocial therapeutic interventions. The indication for psychotherapy is still incipient, and institutions like the Centro de Referência Especializada em Assistência Social-CREAS (Reference Center Specialized in Social Assistance) and the Programa de Atenção à Violência-PAV (Violence Care Program)are responsible for offering psychosocial intervention throughout the national territory (Hohendorff et al.,2015). The document Tipificaşão Nacional de Serviç̧os Socioassistenciais (Brasil, 2009) identifies psychosocial care as that which brings together the knowledge of Psychology and Social Work, seeking to insert the clientele in a socioeconomic perspective, considering the internal world and the context of belonging. In methodological terms, this document highlights the need for the population served by these institutions (CRAS and CREAS) as a preferentially group, allowing users to have a chance of receiving attention.

\section{METHOD}

It is an action research carried out in a public institution to assist victims of sexual violence, children and adolescents. The action takes place in a group psychosocial intervention, whose organization parameter is the psychodramatic session, divided into three distinct moments: warm-up, dramatization and sharing (Gonçalves et al., 1988). During the three moments, subgroups are formed to allow participants to interact more specifically with their peers, that is, adults talking to other adults and children in playful activities with other children (Costa, Penso, et al., 2020). The research has a reference in Barbier (2002) and Merengué (2006). It constitutes a partnership project between a public university and a reference institution in dealing with sexual violence in the Federal District. Both Barbier (2002) and Merengué (2006) share common points when they see research as a social activity that brings benefits to society and the production of specific knowledge on a given topic. Thus, there is a collaboration that involves the political and academic dimensions, through the focus on sexual violence against children, in a little explored condition, which is the reflexivity of these victims when facing the situation suffered.

The context of this action research configures the offer for the application of an assessment and intervention tool, when there is the opportunity for the child's expression in verbal and also playful ways, through the creation of an "as if" environment in which they can do revelations and ghostly approaches mediated by playing, images and construction of scenes (Conceição et al.,2018).It is also considered as a potential resource in conversational situations about sexual violence, as there are many impediments (fear, anger, shame, difficulties in verbal expression) that children present when giving testimony or participating in therapeutic sessions on this topic (Trivedi \& Rejani, 2016; Vrolijk-Boschaart et al., 2018).

The research participants were 13 girls victims of sexual violence perpetrated by a teenager with close kinship. Table 1 seeks to elucidate the complexity of sexual violence committed within family relationships, in which a perpetrator can also become a victim, and vice versa.

Table 1 - Information on victims, adolescent offenders and kinship.

\begin{tabular}{cccc}
\hline Victim & Age & Kinship & Offending Teenager - Age \\
\hline Lili & 7 years & Sister & Dudu 14 years \\
\hline Juju & 4 years & Sister & Didi 13 years \\
\hline Dadá & 18 months & Sister & Pepe 14 years \\
\hline Vevé & 10 years & Cousin & Pepe 14 years \\
\hline Kaká & 7 years & Brother & Totó 13 years \\
\hline Guga & 4 years & Brother & Vevé 10 years \\
\hline Vavá & 6 years & Brother & Vevé 10 years \\
\hline Tatá & 5 years & Sister & Xuxu 13 years \\
\hline Mimi & 2 years & Sister & Xuxu 13 years \\
\hline Gegê & 7 years & Brother & Sosó 12 years \\
\hline Rita & 5 years & Sister & Sosó 12 years \\
\hline Fafá & 9 years & Sister & Zulú 17 years \\
\hline Fafá & 9 years & Zulús sister & Tito 12 years \\
\hline Total & 13 victims & 12 brother/sister, 1 cousin & 9 offenders \\
\hline
\end{tabular}


The instrument used was the observation of two group sessions that resulted in a written record. The sessions had as topic of discussion and reflexivity, the "protection", and the focus of this text is the record of the group process that occurred with the children. The session was led by a psychologist and two observers who are research assistants, students of the Psychology course. The record was performed mainly by the observers, during the session, and after its completion, the record was added by observations provided by the professional. The observations were gathered in the Diário de Campo (Field Journal), an instrument recognized as a research method, with a deep understanding of the subject and the meaning of their actions from documentation, monitoring and direct observation (Andrada, 2018; Jerolmack \& Khan, 2018).

The analysis of the information was carried out based on the Thematic Analysis proposed by Minayo (1996), which recommends an extensive and exhaustive reading of the obtained record, in order to find common and/or complementary meanings that compose a corpus of comprehensibility. After this reading, the criteria for better organization of the analysis corpus were the following directions: who communicates; what communicates; how it communicates; for those who communicate. Thus, it was sought to preserve individual expression, and group interaction that involved the participants and the team members who conducted the sessions.

Ethical care was followed and the research project was approved by the Ethics and Research Committee on Human Beings of the Instituto de Ciências Humanas da Universidade de Brasilia, in the Federal District, with opinion No. 2,054,880, on 05/09/2017, and the amendment was subsequently approved on 04/04/2019, with favorable opinion No. 3,245,222.

\section{RESULTS}

The Protection theme was developed in two sessions that will be detailed here: the first session, which specifically addressed this content, and the third session, which addressed the content that sexual abuse is a crime. In the first session on the topic of Protection, a psychologist, two observers and 14 children were present. The warm-up was performed with the cat and mouse game. All participants build a wheel, in the center is a child (the mouse), and outside the wheel is a child (the cat). The cat needs to force its way into the wheel to catch the mouse. It is the duty of all who make up the wheel to defend the mouse. After the end of the game, questions were asked to provide a reflection on the meanings of the action. Why did the cat want to do evil with the mouse?

Answers: "Because the rat sometimes bothers the cat a lot"; "Because the mouse makes the cat angry"; "Cats don't like mice"; "The mouse keeps going after the cat so the cat goes after it"; "When the parents leave, the mouse keeps disturbing the cat to go after it."Why did the cat get in the wheel? Answers: "Because they left many holes"; "People were not paying attention to the game"; "People do evil with the mouse and therefore they leave a hole"; "The mouse comes out of the protection (wheel), then the cat is looking to catch it later"; "The hunter was slow and I managed to get in".

The slogan of the middle part of the session, Dramatization, was the making of a poster with a collage about protection. In fact, two posters were made: one about protection and the other about unprotection. The protection poster featured the following figures: large family and a father holding a baby; a boy with superpowers and accompanied by protectors, a baby smiling with his mother; mother with her children - all happy and mother hugging; crowd that protects; group of uniformed people (police) who hunt bad people; protecting lion; a baby sleeping with his mother and the two embraced; father and son having fun together; baby on his mother's lap, holding each other.

The poster on unprotection, on the other hand, showed the following: child riding a bicycle alone; one person in the woods alone; dead people; child walking alone; a person alone; two children playing in the water alone; a worried mother and asking for help because a bad man did evil to her children; a mother crying on the phone and holding a baby; two scared and crying children; people walking in the forest and a jaguar watching; a man with his finger over a woman's mouth as a sign of silence; a rhino in the water; one jaguar; and alone. After the reflective conversation about the meanings of the choice of figures, the "Stop!" game was proposed. The Share moment used the socialization of posters with the rest of the people present in the intervention. This game brings together an adult (professional who stays with the children) and offers commands showing what happens when someone wants to touch parts of the body that the child does not want. "My body is mine". This game was presented to the parents, along with the posters. A question was asked by the 
professional - "Someone is going to touch my private parts ..." - and the children in chorus answered: "Stop!". Can the child be hurt? "Stop!". Can you leave the child alone? "Stop!”.

In the third session on Protection, with the development of content on sexual abuse being a crime, a psychologist, two observers and six children were present. The Warm-up was carried out through the story of Little Red Riding Hood (authored by Charles Perrault) (Bettelheim, 2017),connecting with the continuity of the Protection theme. After the narrative, the characters came to life through the dramatization of the coordinators and the children, beginning the Dramatization phase. As in the story narrative, the wolf (played by the professional) went in search of the children. Most of them ran from the wolf (seeing it as danger), initially just as a run, and then realizing the dimensions of danger and seeking protection. Then, the figure of the woodcutter (a professional acting as auxiliary ego) was introduced on the scene, whose function was to arrest the wolf and protect children in danger.

After a lot of laughter and expressions of joy at the play with a lot of action, the Dramatization phase continued through reflexivity: "Hunter and grandma protected Little Riding Hood because the wolf wanted to eat her"; "The bad wolf can never be good"; "I understood that you always have to look around and pay attention to the street". These were some general observations made by the children about the meanings of the characters in the story. Then, a dialogue was established in order to deepen. Some questions asked by the professional: "In people's lives, are there people who do harm? What to do? How to act? Who do you ask for help? Are there people who can sometimes be wolf in our life?". The children's responses followed: “There are bandits, one has to ask for help"; "Parents, grandmother, police, dad, mom, fireman, doctor, doctor". The professional adds: "Ah, so these can be the woodcutter? When the wolf wants to catch, the child can ask for help. What if there is no one to help? What to do when the wolf asks for secrecy?". Children: "Yes. Run, call a street person who is good, find a safe place, hide, tell someone. Do not obey; people should not trust the wolf".

In order to expand reflexivity, a second version of the story of Little Yellow Riding Hood was also presented (Buarque, 2011): she was afraid of everything, she needed to protect herself. She didn't leave the house; she was afraid of the shadow she saw at the door, but when she approached, she saw that it was good. He looked bad, then he looked good; wolf was bad and then got good. They became friends because she found out he was a good guy. The wolf was always undressing; she should have told her mother, but she kept it a secret. Again, a dialogue was sought with questions presented by the professional:"Can we keep a secret? You have to call someone you trust to tell the truth. You can't take your clothes off, do it. You cannot change clothes in front of others. Big people cannot touch any part of the child's body". Children in chorus: "No !!". Then one of the victims said that she wanted to speak, but she was ashamed, and her brother said that he knew what it was, but that he would not speak either. Then he started encouraging his sister to tell and she replied that she had told her mother. So when someone hurts us or does something that we don't want, what should we do? Children's response: "Ask for help! No! Stop! Nobody touches me!"With these exclamations, the victim informs everyone: "This is what my brother did to me, he touched me". All the children supported her by telling her to tell her father and mother.

To end this stage of the Dramatization, a game was introduced: "while $M r$. wolf is not coming", which is a hide and seek. There was the preparation for the Share moment, which would be bringing together all the children, teen brothers and adults, and combining a play to be presented to everyone, with the characters Protection and Unprotection. During the rehearsal for the presentation of Little Red Riding Hood, a child who would play the role of the Guardian Council and say "Sexual abuse is a crime! Wolf, you're under arrest!" did not want to speak, because she insisted that the wolf was not bad and that in the story of Little Yellow Riding Hood he was nice. This child cried and said that "now he (the offending brother) was good because he took care of her, he couldn't be arrested". Faced with the emergence of the paradoxes in which these children find themselves as they were abused by their siblings or cousins, who are also their caregivers, there was a change of intention and the dramatization presented to the other members of the group was about running away from the wolf and saying "Stop!". Everyone was able to participate. 


\section{DISCUSSION}

Resuming the proposal for the interpretation of the information obtained, the discussion was organized in relation to aspects of communicating the victims' reflexivity; construction, interaction and dialogue in this reflexivity; and Psychodrama and play as an instrument for reflexivity. Firstly, the comments are about the choice of the protection theme, which is a central point of the intervention, and which is also used here to demonstrate the gain that the playful action presents to explore the victims' understanding and assimilation of the family reorganization conditions. This reorganization is the objective of a psychosocial intervention (Costa \& Penso, 2010; Costa, Penso, et al., 2020) which includes several people from the nuclear family, the family of origin, the safety net, which involves elements from the areas of health, social assistance, education and justice. Protection/deprotection is considered an aspect that dominates the concern of family members and the routine life of the family, and due to the financial conditions of survival and the lack of adequate places as daycare centers, so that the children can stay while the parents work, they become predominant. It also contributes to this dangerous condition, the allocation of children under the responsibility and care of adolescents, constituting situations that bring vulnerabilities to the occurrence of sexual violence committed within the family and / or by people in the routine circle (Costa, Penso, et al., 2020; Devlin et al., 2019).

The communicated reflexivity - The use of play in therapeutic actions is recognized as a trigger for changes that benefit aspects of the psychological health of children in distress (Klinger et al., 2020; Mercer, 2017). Specifically in relation to discussing sexual abuse, the game allows everyone to present themselves without fear of the topic, because this is a subject that explains secrets and obscure areas of family life. Thus, some prejudices are faced allowing it to reflect on the meaning of the violent actions that took place, because they are and must be seen as violence, which bring suffering to the victims and other family members.

Play builds a relaxed field of action and facilitates a more direct association with the content of the recognition that that violence has brought many affective changes in the interactions of the coexistence group, whether family or social (Costa, Penso, et al., 2020). However, the focus on reflexivity needs to be enhanced by the perception of inherent paradoxes, expanding the possibilities of understanding. After all, the people present in the intervention are the same ones who participated in the scene of sexual violence: the victim, the abuser (father, stepfather, brother, cousin, uncle), loved ones with strong bonds of affection and who do not necessarily break on account the experience of violence. Often, these bonds become more complex due to antagonistic feelings or dependence of different kinds (affective, emotional, financial). Mercer (2017) corroborates the therapeutic action of playing with children, as it allows for changes in the perception of the situation, better communication and clarification of the request for help.

The exposure of the victims' suffering was quite evident in the narrative of the two sessions. Play offers the conditions for children to overcome their verbal limitations, reaching a level of symbolization of their suffering. This revelation is fundamental for changing direct communication with oneself and with others, preventing the continuation of a pattern of verbal and non-verbal interaction between family members that perpetuates the violence (Prigel, 2017).

Dialogue building reflexivity - "Why did the cat want to do evil with the mouse?"The questions are launched in the group dialogue by the team members, who have the responsibility to provoke and maintain the tone of reflexivity, the objective being to encourage dialogue, conversation. Thus, it is possible to create a climate conducive to the breaking of silences. The answers to the question show that children are able to understand the symbolic aspect and respond appropriately: "When the parents leave, the rat keeps disturbing the cat to go after it." The participation of children is relevant and appropriate, showing spontaneity (Marra,2015). On the other hand, they seek to offer various modalities of verbal and imagery language, such as offering clipping and collage works with figures taken from ordinary magazines. With this approach, there is a greater option of associating the theme with various situations of the victims' daily lives, which involve different affects.

The "Stop!" Game is a way of instrumentalizing the victim to adopt simple strategies to avoid intimate contacts, and that the family can learn about at the time of the intervention. It cannot be forgotten that the group action brings together several members of the family, including teenagers who have committed sexual offenses and are not removed from the 
residence, as there is no judicial determination to do so. This is a delicate point of the action, but the presence of the playful dimension, with the creation of an environment of "games", softens the presence of the offending adolescents. As previously seen, the victim is cared for by the offender, who is the one who stays at home throughout the day.

There is an urgent need to advance the concept that in intervention mediated by therapists, victims and offenders cannot be connected, because they remain in close contact even after the revelation.

Participants identified aspects of therapy and supportive relationships from other significant people as elements that promote these changes. Families express a need for all members to be looked at carefully. It is important to know the perspective of the victims, children and adolescents, in relation to the therapeutic changes present in the transformation processes, regardless of which methodology is being adopted (Capella et al., 2018). Therefore, there is a preference for the choice of games or songs that are already known, as is the case of Little Red Riding Hood. Thus, greater adherence and speed is observed in the monitoring of the action.

Psychodrama as an instrument for reflexivity - The warm-up, initially considered unspecific, was the proposal of a game that could create movement and interaction between everyone and that already anticipated the experiences of danger and the need to protect oneself. Note that there is a concern about not identifying that we are talking about sexual abuse. The specific warm-up occurs due to the introduction of reflexivity on the symbolic dimension of perceiving danger and seeking help to face the danger, and that this confrontation is carried out together with other people. In Psychodrama, since warming up, the person follows a path of integration between the physical body, the cognitive aspect and its affective potential, especially in the here and now (Simonetti et al., 2015).

The stage of dramatization is the story of Little Red Riding Hood which provides a broadening and deepening of the reflexive action elaborated in the group. For further enhancement, we sought to maintain the paradoxes present in all conflicting situations. It is a story that brings together a helpless character (girl), an imminent danger (wolf), a person who can offer confrontation to the danger (hunter) and a person who, having a protective function, still needs protection (grandma ). According to Bettelheim (2017), the main theme of this fairy tale is that of devouring, doing good and evil, and how these dimensions are intricate in the most hidden areas of each person, and how one can change roles in the function of interactional situations. The dramatization tries to accommodate the specific anguish about people who play antagonistic roles being the same at different times, within the same family. Adolescent sex offenders are the same adolescents who exercise care and mothering functions. On the other hand, mothers must choose whom they will protect, whether the victims or the adolescents who still need care. Both are their children (Marra \& Costa, 2018).

And finally, at the time of sharing, the goal is to involve everyone in expanding the meanings hidden in the fairy tale and the real situation experienced by families, so that everyone can leave the intervention with provocations carried out by the team members. At this point, the foundation lies in the Morenian conception of spontaneity, and not in pointing out the rigid, closed and immovable structures that often characterize family interactions in situations of sexual violence.

Therapy with an emphasis on playfulness has been increasingly used in the clinical treatment of cases of sexual abuse with children, based on the belief that it is an important, useful and pleasant clinical technique for participants, including those from the technical team (Aarons, 2004). In addition, the game and the "as if" create an emotional distance to talk about feelings that have suffered so much, modulating the approach with avoided content, and helping to find ways out of the conflicting situation. (Bettelheim, 2017; Walters, 2017).

\section{FINAL CONSIDERATIONS}

The dramatization of fairy tales brings together two aspects recommended by therapists with a social/psychodramatic approach: construction of facilitating playful environments and an option for interference in the permanence of the law of silence, so common in cases of intrafamily sexual violence (Klinger et al., 2020; Marra, 2015; Mercer, 2017; Prigel, 
2017; Simoneti et al., 2015; Walters, 2017). The dramatization of fairy tales brings together two aspects recommended by therapists with a social/psychodramatic approach: construction of facilitating playful environments and an option for interference in the permanence of the law of silence, so common in cases of intrafamily sexual violence.

The text's limit is related to the difficulties of making a more reliable record of conversations or behaviors, which could offer more real conditions for apprehending the value and usefulness of the game, for which it is intended to discuss. As it is a theme of interface with justice, there are many objections on the part of participants to allow recording in audio or video. Furthermore, other aspects to be researched are envisaged. The perception of the experience of coping with content that involves shame, anger and other negative feelings, and the conversation that occurs with the participation of people within the family circle and people belonging to other family nuclei.

\section{AUTHORS' CONTRIBUTION}

Conceptualization: Moreira DL, Costa LF; Investigation: Moreira DL, Costa LF; Writing: Moreira DL, Costa LF; Supervision: Moreira DL, Costa LF.

\section{ACKNOWLEDGMENT}

Not applicable.

\section{DATA AVAILABILITY STATEMENT}

All data were analyzed or generated in the current study

\section{FUNDING}

Not applicable.

\section{REFERENCES}

Aarons, J. D. (2004). The Use of Play Therapy with Child Victims of Sexual Abuse. Columbia Social Work Review, 2(1), 27-34. https://doi.org/10.7916/cswr.v2i1.1842

Andrada, C. F. (2018). O método no centro: Relatos de campo de uma pesquisa psicossocial de perspectiva etnográfica. Psicologia USP, 29(2), 236-245. https://doi.org/10.1590/0103-656420170025

Barbier, R. (2002). A pesquisa-ação. Plano.

Bettelheim, B. (2017). A psicanálise dos contos de fadas (34a ed.). Paz \& Terra.

Brasil (2009). Tipificação Nacional de Serviços Socioassistenciais. Resolução no 109 de 11 de novembro de 2009. http:// www.assistenciasocial.al.gov.br/sala-de-imprensa/arquivos/folder.2010-11-23.9973739377/Tipificao.pdf

Buarque, C. (2011). Chapeuzinho Amarelo (27a ed.). José Olympio.

Capella, C., Gutiérrez, C., Rodríguez, L., \& Gómez, C. (2018). Change during psychoterapy: The perspective of children and adolescents who have been sexually abused. Research in Psychoterapy: Psychopatology, Process and Outcome, 21, 24-39._https://doi.org/10.4081/ripppo.2018.288

Conceição, M. I. G., Penso, M. A., Costa, L. F., Setubal, C. B., \& Wolff, L. S. (2018). O Psicodrama na Intervenção Psicossocial com Adulto Autor de Violência Sexual. In L. F. Haigzang, P. I. C. Gomide, \& G. M. Rocha (Eds.), Psicologia Forense. Temas e Práticas (pp. 89-110). Juruá. 
Costa, L. F. \& Penso, M. A. (2010). A dimensão clínica das intervenções psicossociais com adolescentes e famílias. In M. M. Marra \& L. F. Costa (Eds.), Temas da Clínica do Adolescente e da Família (pp. 201-214). Ágora.

Costa, L. F., Penso, M. A., Santos, S. R. M. L.B., \& Moura, M. G. (2020). Atuação sistêmica na comunidade: O grupo multifamiliar no contexto do adolescente que cometeu ofensa sexual. In J. A. A. Mendes \& J. B. N. F. BucherMaluschke (Eds.), Perspectiva sistêmica e práticas em psicologia: temas e campos de atuação (pp. 207-224). CRV.

Costa, L. F., Setubal, C. B., Wolff, L. S., \& Penso, M. A. (2020). Uma Perspectiva Sistêmica e de Gênero na Atenção ao Adulto Ofensor Sexual. In J. A. A. Mendes \& J. B. N. F. Bucher-Maluschke (Eds.), Perspectiva sistêmica e práticas em psicologia: temas e campos de atuação (pp. 225-243). CRV.

Devlin, M. J., Hill, L., Berry, J., Felder, K., \&Wilson, C. (2019). Therapeutic Practices for Sexually Abused Children and Adolescents: Resources for Marriage, Family, and Couples' Counselors. The Family Journal: Counseling and Therapy for Couples and Families, 27(4), 359-365. https://doi.org/0.1177/1066480719844017

Dorsey, S., McLaughlin, K. A., Kerns, S. E. U., Harrison, J. P., Lambert, H. K., Briggs, E. C., Cox, J. R., \& AmayaJackson, L. (2017). Evidence Base Update for Psychosocial Treatments for Children and Adolescents Exposed to Traumatic Events. Journal of Clinical Child E Adolescent Psychology, 46(3), 303-330. https://doi.org/10.1080/1537441 6.2016.1220309

Gonçalves, C. S., Wolff,J. R., \& Almeida,W. C. (1988)._Lições de Psicodrama: Introdução ao Pensamento de J. L. Moreno. Ágora.

Hohendorff, J., Habigzang, L. F., \& Koller, S. H. (2015). Psicoterapia para Crianças e Adolescentes ítimas de Violência Sexual no Sistema Público: Panorama e Alternativas de Atendimento. Psicologia: Ciência E Profissão, 35(1), 182-198. https://doi.org/10.1590/1982-3703000202014

Hollander, E. M. \& Craig, M. (2013). Working with Sexual Offenders via Psychodrama. Sexual Offender Treatment, 8(2), 1-15. http://www.sexual-offender-treatment.org/124.html

Jerolmack, C. \& Khan, S. (2018). Approaches to ethnography: Analysis and representation in participant observation. Oxford University Press.

Klinger, E. F., Barcelos, G. V., Azevedo, W. A., \& Oliveira, D. P. (2020). O brincar como recurso de promoção à saúde em psicoterapia. ECOS: Estudos Contemporâneos da Subjetividade, 10(1), 145-155. http://www.periodicoshumanas.uff. br/ecos/article/view/2200

Marra, M.M. (2015). Diante das violências: Abordagem psicodramática. In R. Payá (Ed.), Intercâmbio das Psicoterapias: Como cada Abordagem Psicoterapêutica compreende os Transtornos Psiquiátricos (2a ed., pp. 393-411). Guanabara KooganRoca.

Marra, M. M. \& Costa, L. F. (2016). A família em contexto de abuso sexual: Significados e construções narrativas. In M. Grandesso (Ed.), Práticas colaborativas e dialógicas em distintos contexto e populaçôes: Um diálogo entre teoria e prática (pp. 491-512). CVR.

Marra, M. M. \& Costa, L. F. (2018). Entre a revelação e o atendimento: família e abuso sexual. Avances en Psicología Latinoamericana, 36(3), 459-475. https://doi.org/10.12804/revistas.urosario.edu.co/ap1/a.3564

Mercer,J. (2017). Evidence of Potentially Harmful Psychological Treatments for Children and Adolescents. Child and Adolescent Social Work Journal, 34, 107-125. https://doi.org/10.1007/s10560-016-0480-2

Merengué, D. (2006). Psicodrama e Investigação Científica. In A. M. Monteiro, D. Merengué, \& V. Brito (Eds.), Pesquisa Qualitativa e Psicodrama (pp. 57-87). Ágora.

Minayo, M. C. S. (1996). O Desafio do Conhecimento: Pesquisa Qualitativa em Saúde (4a ed.). Hucitec/Abrasco.

Moreno, J. L. (1983). Fundamentos do Psicodrama. Summus.

Moreno, J. L. (1993). Psicoterapia de Grupo e Psicodrama. Psy.

Navaei, M., Akbari-Kamrami, M., Esmaelzadeh-Saeieh, S., Farid, M., \& Tehranizadeh, M. (2016). Effect of Group Counseling of Parent's Efficacy, Knowledge, Attitude, and Communication Practice in Preventing Sexual Abuse of 
Children Aged 2-6 Years: A Randomized Controlled Clinical Trial. International Journal of Community Based NursingMidwifery, 6(4), 285-292. https://www.ncbi.nlm.nih.gov/pmc/articles/PMC6226606/

Prigel, M. (2017). Integrating Play Therapy and Heart-Centered Energetic Psychodrama: A Profound Treatment for Traumatized Children. Journal of Heart-Centered Therapies, 20(2), 45-74. https://go.gale.com/ps/anonymous?id=G ALE\%7CA516447801\&sid=googleScholar\&v=2.1\&it=r\&linkaccess=abs\&issn=15205495\&p=HRCA\&sw=w

Simonetti, G. S., Maiolino W. S. S., \& Severino, M. F. S. (2015). Psicodrama: Cuerpo, espacio y tempo hacia la libertad creadora. Arteterapia: Papeles de arteterapia y educación artística para la inclusión social, 10, 139-151. https://doi. org/10.5209/rev_ARTE.2015.v10.51688

Trivedi, R. R. \& Rejani, T. G. (2016). Expressive Therapy with Children who Were Sexually Abused: An Overview. World Journal of Research and Review, 3(4), 78-83.

Vrolijk-Boschaart, T. F., Brilleslijper-Kater, S. N., Benninga, M. A., Lindauer, R. J. L., \& Teeuw, A. H. (2018). Clinical practice: recognizing child sexual abuse - what make it so difficult? European Journal of Pediatrics, 177, 1343-1350. https://doi.org/10.1007/s00431-018-3193-z

Walters, R. (2017). Fairytales, psychodrama and actiom methods: ways of helping traumatizes children to heal. Zeitschfrit für Psychodrama und Soziometrie, 16, 53-60. https://doi.org/10.1007/s11620-017-0381-1

Webster, G. (2018). Psychoanalytic Complex Theory: An Aplication to the Treatment of Child Sexual Offenders. Psychoanalytic Psychology, 35(1), 83-92. https://doi.org/10.1037/pap0000120 